DOI: https://doi.org/10.47405/mjssh.v6i1.588

\begin{tabular}{|c|c|}
\hline (8) & Malaysian Journal of Social Sciences and Humanities (MJSSH) \\
\hline Malaysian Journal of & Volume 6, Issue 1, January 2021 \\
\hline 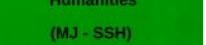 & e-ISSN : 2504-8562 \\
\hline & $\begin{array}{l}\text { Journal home page: } \\
\text { www.msocialsciences.com }\end{array}$ \\
\hline
\end{tabular}

\title{
To What Extent is the Lack of Education Awareness among Kensiu Indigenous Children in Baling, Kedah? A Preliminary Study
}

\author{
Muhammad Wafi Ramli1, Sharifah Rohayah Sheikh Dawood1 \\ ${ }^{1}$ Geography Section, School of Humanities, Universiti Sains Malaysia (USM) \\ Correspondence: Sharifah Rohayah Sheikh Dawood (sdawood@usm.my)
}

\begin{abstract}
The indigenous people, particularly the children, are perpetually challenged with education issues that have been going on for too long. Indigenous children have the capacity to bring changes and progress in their communities. To achieve that, they should be nurtured early on the awareness and importance of education. This paper aims to identify the level of education awareness among indigenous children through behavioural, personal, and environmental factors. A total of 30 respondents consisting of Kensiu indigenous children aged 7 to 12 have participated in the survey conducted in Kampung Lubuk Legong located in Baling district. Descriptive statistical analysis is applied to obtain frequency, percentage, and mean values. Overall, the finding indicates that the level of education awareness among the respondents is moderate, where the behavioural, personal, and environmental factors recorded a mean value of $(\mu=2.41),(\mu=2.96)$, and $(\mu=2.24)$ respectively. This study aspires to urge holistic education development strategies in order to raise the level of education awareness among indigenous children so that they will not be left behind.
\end{abstract}

Keywords: awareness, education, Kensiu, indigenous children

\section{Introduction}

Indigenous people in the Peninsular Malaysia or also known as Orang Asli are divided into three racial groups; namely Senoi, Negrito, and Proto-Malay. These three main groups are divided into eighteen smaller ethnic groups. The Senoi group is composed of the ethnics of Semoq Beri, Temiar, Semai, Jahut, Che Wong, and Mah Meri. Meanwhile, the Negrito group is composed of the ethnics of Kensiu, Kintak, Jahai, Mendriq, Bateq, and Lanoh, and the Proto-Malay group is composed of the ethnics of Temuan, Duano, Seletar, Jakun, Kanaq, and Semelai (Ramli, 2020). The classification of each of these ethnic group is characterised through their physical form, language, culture, customs, and economic functions (Harun \& Idris, 2009).

Education is an important element for social and economic growth in shaping a prosperous society (Selvaratnam et al., 2012). It is the key factor that is able to influence self-development and shape the future of an individual (Shah et al., 2015). According to Renganathan (2016), education is essential in ensuring improvements on the quality of life among indigenous people. Manjunatha and Gangadhar (2018) asserted that education is actually an input that is not only important for their financial development, but also essential in strengthening their society in facing upcoming life challenges. 
As Malaysian citizens, the indigenous community has also been given the same rights as other communities in matters involving socio-economic development, especially in education. The Department of Orang Asli Development (JAKOA) acts as the responsible party for safeguarding the welfare and development of indigenous people in the country. Currently, basic facilities such as resettlement scheme, health, transportation, water and electricity supply, and education and have been provided to their domestic establishments. The administration of education for the indigenous communities has long been paid attention to by the government, where numerous efforts are made to improve their overall life quality.

However, the reality of today is that there are still a large number of indigenous people who are missing out on education compared to other communities, and they are constrained by various obstacles in obtaining access to proper education in the country (Marzuki et al., 2014). A lot of them are still behind (Nor et al., 2018), and they have a high dropout rate in all levels, from preschool to higher education institutions (Selvaratnam et al., 2012). This is believed to happen due to the low education awareness among this community, especially children (SUHAKAM, 2010; Salleh \& Ahmad, 2009). To further understand this issue, the present study aims to identify the level of education awareness among indigenous people through a case study upon the Kensiu ethnic in Baling, Kedah.

\section{Literature Review}

The issue of academic performance in school has always been associated with indigenous people (Hasbullah, 2015). Sims (2011) noted that indigenous children are often addressed with the issue of poor attendance and low academic achievement. Various factors have contributed to this issue, one of them is due to low education awareness, which consequently results in higher dropout rates. The lack of education awareness among indigenous people, especially parents, have caused their children to lose interest in learning and knowledge seeking. Some indigenous parents even have a negative perception upon education, where school education is considered insignificant for their survival (Abdullah, 2010). In fact, there are indigenous parents who only considered school as a place for their children to play and eat (Salleh \& Ahmad, 2009).

The low level of education among indigenous parents themselves is a factor that contributes to their ignorance upon the education of their children (Wahab et al., 2016). Edo (2012) contended that indigenous parents who do not understand the importance of education will eventually cause their children to also lose interest in school. There are also a handful of indigenous parents who would let their children skip school, due to the perception that school is nonessential (Wahab et al., 2013). The knowledge gained in school is perceived as a waste of money, as they do not receive any immediate return. Furthermore, low education awareness can be seen in the lack of parental involvement in their children's learning process. One of the contributing factors is due to the parents themselves are not well equipped with sufficient knowledge to teach their children (Nor et al., 2018). The lack of the parents' involvement with school management is also seen as a problem where they only attend school meetings just to enjoy the meal (Hanafi et al., 2014).

Furthermore, the attitude and behaviour of the indigenous children is also a concerned element in factors causing school dropouts. Indigenous children seem to get bored easily with classroom activities; they are more interested in teasing their friends, running, and jumping in the class (Salleh \& Ahmad, 2009). Hanafi et al. (2014) noted that the low level of motivation among indigenous children is in fact a challenge for teachers. There are also cases where indigenous children who failed to show progress in their studies tend to put the blame on teachers (Wong \& Perumal, 2013). On top of that, personal activities such as taking care of their siblings at home or following their parents for hunting and gathering forest products is also one of the contributing factors (Hanafi et al., 2014).

Dropouts are also believed to be caused by environmental factors, such as schools and teachers. Indigenous children who are familiar with the traditional socialization process would face difficulties adapting to the school system (Nor et al., 2018). A study by Patel (2014) shows that a large number of indigenous parents stated that their children simply do not want to go to school due to lack of interest 
in doing so. Other factors include their disinterest upon the teachers and the subjects, unattractive classroom atmosphere, culturally inappropriate curriculum syllabus, and the discrimination from students of other races (Ishak \& Low, 2013; Edo, 2006; Tyler \& Lofstrom, 2009).

Environmental factors involving surrounding figures also play an important role, especially those who can be a source of inspiration. Hanafi et al. (2014) stated that role models are an important source of inspiration for indigenous children to succeed. The lack of role models will influence the interest and motivation of indigenous children to learn. Marzuki et al. (2014) stated that their far secluded domestic establishment is also a barrier, due to the scarcity of proper environment needed for a proper learning process, such as transportation.

The clash between their traditional cultural celebration and school schedule is also a factor causing their poor attendance (SUHAKAM, 2010). As agreed by Hanafi et al. (2014), indigenous students do not attend schools because they prefer going to festivals and enjoy the fruits in season instead. There are also cases where the attendance of indigenous children to school are inconsistent in their first year, and they will continue to skip school during the fruit season for about a year or two (Talib \& Muslim, 2007).

\section{Methods}

\section{Participants}

This study was conducted through a purposive sampling method by selecting indigenous children as respondents. A total of 30 respondents consisting of primary school students aged 7 to 12 years old were selected.

\section{Study Area}

The survey was conducted in Kampung Lubuk Legong located in Baling district, Kedah. It is the one and only indigenous people's area in Kedah state located in the suburbs. The Kensiu ethnic group is the only group of indigenous people living in the area.

\section{Instrument}

This study used a survey form instrument. The survey form was divided into 4 sections which includes the respondents' profile, behavioural factor, personal factor, and environmental factor. Each item in the survey involved the use of a 4-point Likert scale, namely 1: Strongly Disagree; 2: Disagree, 3: Agree; and 4: Strongly agree.

\section{Data Collection}

The data collection process was assisted by Mr. Razali Kulim (head of village) or also known as Tok Batin and Mr. Ubal Kulim (Imam in the village). They gathered all the respondents and placed them in the community hall in the village. After that, the researchers started the data collection process by distributing the survey forms to all respondents.

\section{Data Analysis}

Data obtained from the survey forms were analysed using Statistical Package for Social Sciences (SPSS) software version 26.0 to obtain the frequency, percentage, and mean values. Data is presented in tabular form for each section. The description for each analysis are descriptively interpreted. The scale of interpretation by Shaari et al. (2008) is applied to determine the level of mean values; low level (1.0 to 2.0), medium level (2.01 to 3.00), and high level (3.01 to 4.00). 


\section{Findings and Discussion}

\section{Respondent's profile}

Table 1 shows the profiles of the respondents. Majority of the respondents in this study were Muslims comprising of a total of 19 female respondents $(63.3 \%)$ and 11 male respondents (36.7\%). For the age category, a total of 6 respondents $(20.0 \%)$ aged 7 years old (standard 1), 4 respondents (13.3\%) aged 8 years old (standard 2), 7 respondents (23.3\%) aged 9 years old (standard 3), 4 respondents (13.3\%) aged 10 years old (standard 4), 3 respondents (10.0\%) aged 11 years old (standard 5), and 6 respondents (20.0\%) aged 12 years old (standard 6).

Table 1: Respondents' profile

\begin{tabular}{lcc}
\hline Categories & $\mathbf{n = 3 0}$ & Percentage (\%) \\
\hline Age & & \\
7 years old (standard 1) & 6 & 20.0 \\
8 years old (standard 2) & 4 & 13.3 \\
9 years old (standard 3) & 7 & 23.3 \\
10 years old (standard 4) & 4 & 13.3 \\
11 years old (standard 5) & 3 & 10.0 \\
12 years old (standard 6) & 6 & 20.0 \\
Gender & & \\
Male & 11 & 36.7 \\
Female & 19 & 63.3 \\
& & \\
Religion & & \\
Islam & 30 & \\
\hline
\end{tabular}

\section{BehaviouralFactor}

Table 2 shows items regarding the behavioural factors. Overall, a majority of the respondents indicated a moderate level of agreement in behavioural factors which recorded a mean value of $(\mu=2.41)$. All items for behavioural factors show moderate mean values. However, referring to all items under this category, the item that is in the highest position is "I always complete the homework given by teachers" with a mean value of $(\mu=2.57)$. This is believed to be influenced by the respondents' sense of responsibility to complete the homework given by their teachers. Assigning homework is a part of the effort to encourage indigenous children to be diligent, responsible, and trustworthy in doing a particular task. They are also able to develop discipline by being responsible with the homework given by the teachers. This statement is also supported by Asaron et al. (2013) and Mamat (2001), where they agree that homework given by teachers can provide opportunities for students to deal with learning problems, understand a topic according to their rate of self-improvement outside of school hours, create curiosity, help students to manage time wisely, and help students to be more responsible, disciplined, and independent.

Table 2: Behavioral factor

\begin{tabular}{lcc}
\hline Items & $\begin{array}{c}\text { Mean } \\
\text { value }\end{array}$ & Level \\
\hline I always complete the homework given by teachers & 2.57 & Moderate \\
I always do revision in my leisure time & 2.47 & Moderate \\
I pay full attention in classes & 2.40 & Moderate \\
I like to share knowledge with friends and family & 2.33 & Moderate \\
I always ask my teachers if I do not understand something & 2.30 & Moderate \\
\hline
\end{tabular}




\begin{tabular}{lll}
\hline Overall mean value & 2.41 & Moderate \\
\hline
\end{tabular}

Meanwhile, the item that is in the lowest position is "I always ask my teachers if I do not understand something" with a mean value of $(\mu=2.30)$. This is believed to be caused by the shyness or anxiety in speaking up to ask questions. A Malay proverb says; "malu bertanya sesat jalan", which carries the meaning 'if you're ashamed of asking, you'll get lost". This highly reflects the reality experienced by these indigenous children. When they are ashamed of asking, it will indirectly cause them to miss out in learning. This is supported by Ahmad (2014), in which he stated that one of the problems faced by teachers with indigenous students are shyness, quietness and passiveness, in which they rarely have questions to ask and they are often reluctant to answer when asked. Salleh and Ahmad (2009) is also in support of this, where they claimed that indigenous students possess a low self-concept, and they are often embarrassed to speak out or ask questions.

\section{PersonalFactor}

Table 3 shows the items regarding personal factors. Overall, a majority of the respondents indicated a moderate level of agreement for personal factors which recorded a mean value of $(\mu=2.96)$. There are only two items that show a high mean value and the rest are moderate. However, referring to all the personal factor items, the items that are in a high position is "I have high ambitions" with a mean value of $(\mu=3.10)$ and the item of "I want to study at university level" with a mean value of $(\mu=3.03)$. Every human being are ambitious, where they desire to succeed and achieve self-improvement. The same spirit can be seen among these indigenous children. During the data collection session, the researcher s took the opportunity to ask question to all respondents about their future ambitions. A majority of respondents stated that they dream of becoming a teacher, policeman, doctor, pilot, or an astronaut. This is an interesting insight for the researchers. This finding is in line with the study by Nor et al. (2018), where they found that indigenous students too aspire to have careers, such as becoming a teacher, mainly due to the perception that a teacher is respected by the society. This particular finding indicates that these students are ready to go beyond their long time traditional economical customs, such as collecting forest products and hunting animals (Rahman, 2018).

Table 3: Personal factor

\begin{tabular}{lcc}
\hline Items & $\begin{array}{c}\text { Mean } \\
\text { value }\end{array}$ & Level \\
\hline I have high ambitions & 3.10 & High \\
I want to study at university level & 3.03 & High \\
Education is important in my life & 2.97 & Moderate \\
Knowledge can make myself advance & 2.87 & Moderate \\
I want to change my family destiny to be better & 2.83 & Moderate \\
Overall mean value & $\mathbf{2 . 9 6}$ & Moderate \\
\hline
\end{tabular}

The second highest item is "I want to study at university level". Pursuing education at the university level is also desirable among the respondents. This shows that they are well exposed to the available levels of education. To maintain these ambitions, they should be nurtured and cultivated with education awareness from an early stage, which would help them to stay in school. They have to successfully go through every level of schooling to reach the tertiary education level. As mentioned by Hanafi el al. (2014), primary and secondary levels of education are the basis for getting access to education at the tertiary level.

Meanwhile, the item that is in a low position is "I want to change my family destiny to be better" with a mean value of $(\mu=2.83)$. This suggests that they are comfortable with their current household condition. This finding is in line with the statement by Hanafi el al. (2014) which indicates that most indigenous students are satisfied with their parent's adequate lifestyle, despite not being highly educated. As a result, indigenous students are less motivated to change the destiny of their families. 


\section{Environmental Factor}

Table 4 shows the items regarding environmental factors. Overall, a majority of the respondents indicated a moderate level of agreement for environmental factors which recorded a mean value of $(\mu=2.24)$. All items show a moderate mean value and only one item shows a low mean value. However, referring to all environmental factor items, the item that is in the highest position is "teachers are very helpful in my studies" with a mean value of $(\mu=2.73)$. This is achieved through the encouragement and motivation from teachers upon the students. Teachers play an important role as an agent of change in the lives of indigenous children. Teachers who are in full support of the growth of indigenous children are noble and admirable. This finding is in line with a study by Nor et al. (2018) which acknowledged the influence of teachers in shaping the attitudes and perceptions of indigenous students towards learning.

Table 4: Environmental factor

\begin{tabular}{lcc}
\hline Items & $\begin{array}{c}\text { Mean } \\
\text { value }\end{array}$ & Level \\
\hline Teachers are very helpful in my studies & 2.73 & Moderate \\
The success of the people around me encouraged me to succeed & 2.37 & Moderate \\
My friends always help me in studies & 2.17 & Moderate \\
The school atmosphere gives me a good mood & 2.07 & Moderate \\
My parents care about my studies & 1.90 & Low \\
Overall mean value & $\mathbf{2 . 2 4}$ & Moderate \\
\hline
\end{tabular}

Meanwhile, the item that is in a low position is "my parents care about my studies" with a mean value of $(\mu=1.90)$. This is believed to be caused by the ignorance of parents' attitude upon their children's education. This can indirectly affect the children's interest to continue learning in school. In a conversation between the researchers and the respondents, it is revealed that their parents rarely ask about their homework and the parents pay little attention to their school progress. For instance, the parents will not wake them up if they overslept. Some parents also have to leave the home early for their daily routine, therefore leaving the children unprepared for school. As previously asserted by Wahab et al. (2016) and Edo (2012), parents are a major contributor to the educational achievement of indigenous children, and such poor attitude portrayed by the parents have affected the children's interest in education.

\section{Conclusion}

Conclusively, this study successfully demonstrated that the level of education awareness among Kensiu indigenous children is at a moderate level. Education is essential for the survival of indigenous people. Without education, they cannot afford to be competitive in this era of modernization. Indigenous children should be given greater attention to, and they must be cultivated with the desire to study and stay in school. Every indigenous children has their dreams and ambitions. Children are the leaders of the future, and their ambitions should not be obstructed due to the of education awareness. Thus, the responsible parties such as the Ministry of Education, school managements, and NGOs must step up and show more efforts in nurturing the interest of education among indigenous children. This is significantly importance, as these children possess a high potential to bring about a change for the betterment of their communities. Programs related to motivation, awareness, and careers should be held in their schools to provide them a better exposure. In addition, indigenous parents should also be educated through education awareness programs to introduce and expose them to the value of education in life. It is important to emphasize that the development of the children's interest in learning starts at home. The children's interest in school should start from parents with high education awareness. This study is hoped to benefit and inspire every responsible party to continue their noble efforts in embedding high education awareness among the indigenous community, especially children, in order to produce quality human capital. 


\section{Acknowledgement}

The authors would like to acknowledge Universiti Sains Malaysia for funding this research through Research Grant University (RU) (Grant account number: 1001/PHUMANITI/8016024). Also, our sincere gratitude to Mr. Razali Kulim, Mr. Ubal Kulim, Mr. Mohd Syarull Azlan Yaakob, and Kensiu indigenous children for participating in this research.

\section{References}

Abdullah, R. (2010). Keciciran pendidikan murid orang asli: Kajian kes di negeri Terengganu. Prosiding Seminar Internasional Perbandingan Sistem Pendidikan Indonesia dan Malaysia 2010. Universitas Pendidikan Indonesia.

Ahmad, J. (2014). Masalah pembelajaran dan penguasaan Bahasa Melayu sebagai bahasa kedua dalam kalangan murid-murid Kensiu: Satu kajian kes (PhD dissertation). Retrieved from Universiti Utara Malaysia.

Asaron, M., Tunggak, B., Zainal, K., \& Kassim, J. (2013). Pengurusan kerja rumah dalam kalangan guru di Malaysia. Sains Humanika, 62(1), 1-6.

Edo, J. (2006). Retorik pembangunan orang asli. In Yacob, M.F. (Eds.), Malaysia menangani perubahan dan pembangunan. Kuala Lumpur: Universiti Malaya Press.

Edo, J. (2012). Pendidikan orang asli: Harapan dan peluang. In Abdullah, R., Simin. M.H.A., Abdullah, A., \& Mansor, Z. (Eds.), Pendidikan orang asli dalam arus perdana. Terengganu: Universiti Sultan Zainal Abidin Press.

Harun, M.F.M., \& Idris, N.A.H. (2009). Pembangunan masyarakat orang asli: Dilema miskin dan terpinggir. Shah Alam: Universiti Teknologi MARA Press.

Hanafi, W.A.W., Ahmad, S., \& Ali, N. (2014). Faktor budaya dan persekitaran dalam prestasi pendidikan anak orang asli Malaysia: Kajian kes di Kelantan. Geografia-Malaysian Journal of Society and Space, 10(5), 107-122.

Hasbullah, Z. (2015). Tingkah laku bermasalah dalam kalangan pelajar orang asli di sebuah sekolah menengah ( $\mathrm{PhD}$ dissertation). Retrieved from Universiti Pendidikan Sultan Idris.

Ishak, Z, \& Low, S.F. (2013). Truancy among Malaysian students: An analysis based on ethnicity. Journal of Teaching and Education, 2(2), 331-338.

Mamat, Z. (2001). Tinjauan tentang pengurusan kerja rumah di kalangan guru-guru sekolah menengah daerah Raub, Pahang Darul Makmur (Master dissertation). Retrieved from Universiti Kebangsaan Malaysia.

Manjunatha, B.R., \& Gangadhar, M.R. (2018). School dropout among Jenukuruba tribal children in Karnataka. IMPACT: International Journal of Research in Humanities, Arts and Literature, 6(1), 31-40.

Marzuki, M., Mapjabil, J., \& Mohd Zainol, R. (2014). Mengupas keciciran pelajar orang asli Malaysia: Suatu tinjauan ke dalam isu aksesibiliti sekolah. Geografia-Malaysian Journal of Society and Space, 10(2), 189-198.

Nor, M.M.M., Sukimi, M.F., \& Nor, M.N.M. (2018). Kesedaran pendidikan dan minat kerja pelajar orang asli suku kaum Jakun di Rompin, Pahang. Geografia-Malaysian Journal of Society and Space, 14(1), 72-86.

Patel, T. (2014). Dropping out of school in Malaysia: What we know and what needs to be done. Kuala Lumpur: Institute for Democracy and Economic Affairs.

Rahman, H.A. (2018). World view masyarakat orang asli dan pelestarian alam sekitar. Prosiding Seminar Antarabangsa Arkeologi, Sejarah, Bahasa dan Budaya di Alam Melayu (ASBAM) 2018. Lombok, Indonesia.

Ramli, M.W. (2020). Keadaan ekonomi komuniti orang asli Semoq Beri di Kampung Sungai Berua, Terengganu. e-Bangi-Journal of Social Sciences and Humanities, 17(6), 68-79.

Renganathan, S. (2016). Educating the orang asli children: Exploring indigenous children's practices and experiences in schools. The Journal of Educational Research, 109(3), 275-285.

Salleh, M.J., \& Ahmad, A.R. (2009). Kesedaran pendidikan dalam kalangan masyarakat orang asli. In Ahmad, A.R., \& Jelas, Z.M. (Eds.), Masyarakat orang asli: Perspektif pendidikan dan sosiobudaya. Bangi: Universiti Kebangsaan Malaysia Press. 
Selvaratnam, D.P., Jaafar, A.H., Salleh, N., Othman, R., \& Idris, S.H. (2012). Transformasi modal insan melalui peningkatan pendidikan: Kajian kes komuniti orang asli di Cameron Highlands, Pahang. Prosiding Persidangan Kebangsaan Ekonomi Malaysia ke VII, 2, 1215-1224.

Shaari, A.S., Yusof, A., Khan, J., Khan, M., Tang, S.M., \& Lim, K.T. (2008). Keadilan penilaian prestasi dalam kalangan guru dan hubungannya dengan motivasi kerja dan prestasi akademik sekolah. International Journal of Management Studies (IJMS), 15, 159-176.

Shah, B.T., Halim, L, \& Iksan, Z. (2015). Kaedah bermain dalam meningkatkan minat murid orang asli terhadap sains. International Conference on Language, Education, and Innovation 2015. Kuala Lumpur, Malaysia.

Sims, M. (2011). Early childhood and education services for indigenous children prior to starting school. Australia: Australian Institute of Health and Welfare and Australian Institute of Family Studies.

Suruhanjaya Hak Asasi Manusia Malaysia (SUHAKAM). (2010). Laporan status hak pendidikan kanak-kanak orang asli. Kuala Lumpur: SUHAKAM.

Talib, J., \& Muslim, N. (2007). Bagaimana kanak-kanak orang asli gagal di sekolah? MALIM: Jurnal Pengajian Umum Asia Tenggara, 8, 51-76.

Tyler, J.H., \& Lofstrom, M. (2009). Finishing high school: Alternative pathways and dropout recovery. The Future of Children, 19(1), 77-103.

Wahab, N.A., Mustapha, R., \& Talib, J.A. (2016). Membangun modal insan orang asli: Kajian peranan dan penentuan matlamat pendidikan dalam kalangan ibu bapa masyarakat orang asli di Kuantan, Pahang. Geografia-Malaysian Journal of Society and Space, 12(3), 1-10.

Wahab, N.B.A., Mohamed, M., Hassan, A., \& Haron, M.N. (2013). Penerapan elemen sekolah rimba Malaysia dalam kalangan murid orang asli. 2nd International Seminar on Quality and Affordable Education 2013. Universiti Teknologi Malaysia.

Wong, B.W.K. \& Perumal, C. (2013). The issues of teaching and learning in the primary school of orang asli: A case study of Sekolah Kebangsaan Senderut, Kuala Lipis, Pahang. In Saat, G., Said, S, \& Ahmad, S.A. (Eds.), Issues in Development in Malaysia and Nigeria: Multidimensional approaches. Sarawak: Universiti Malaysia Sarawak Press. 